\title{
Bath treatment, an alternative method for the administration of the quinolones flumequine and oxolinic acid to halibut Hippoglossus hippoglossus, and in vitro antibacterial activity of the drugs against some Vibrio sp.
}

\author{
O. B. Samuelsen ${ }^{1, *}$, B. T. Lunestad ${ }^{2}$ \\ ${ }^{1}$ Institute of Marine Research, Department of Aquaculture, Strandgaten 229, N-5024 Bergen, Norway \\ ${ }^{2}$ Directorate of Fisheries, Department of Quality Control, Central Laboratory, Strandgaten 229, N-5002 Bergen, Norway
}

\begin{abstract}
Administration of flumequine and oxolinic acid to halibut Hippoglossus hippoglossus by bath resulted in significant tissue levels of both the antibacterials. Bath treatment using $150 \mathrm{mg} \mathrm{l}^{-1}$ of flumequine and $200 \mathrm{mg} \mathrm{l}^{-1}$ of oxolinic acid for $72 \mathrm{~h}$ resulted in flumequine concentrations of $14.2 \mu \mathrm{g} \mathrm{g}^{-1}$ in muscle and $85.4 \mu \mathrm{g} \mathrm{g}^{-1}$ in abdominal organ homogenate and oxolinic acid concentrations of $9.4 \mu \mathrm{g}$ $\mathrm{g}^{-1}$ in muscle and $72.6 \mu \mathrm{g} \mathrm{g}^{-1}$ in abdominal organ homogenate. Excretion of both antibacterials was rapid and characterised by elimination half-lives $\left(t_{1 / 2}\right)$ of 10 and $15.6 \mathrm{~h}$ respectively for flumequine and oxolinic acid in muscle and 9.8 and $15.0 \mathrm{~h}$ respectively in the abdominal organ homogenate. The corresponding elimination times $\left(E_{\mathrm{t}}\right)$ were 6.5 and $8 \mathrm{~d}$ respectively for flumequine and oxolinic acid in muscle and 7.5 and $9 \mathrm{~d}$ respectively in abdominal organ homogenate when a maximum residue concentration of $0.05 \mathrm{\mu g} \mathrm{g}^{-1}$ was applied for both drugs. The minimum inhibitory concentration (MIC) against strains of Vibrio sp. ranged from 0.015 to $1.0 \mu \mathrm{g} \mathrm{m}^{-1}$ for flumequine and 0.015 to $0.5 \mu \mathrm{g} \mathrm{m} \mathrm{m}^{-1}$ for oxolinic acid. Following bath treatment, tissue levels of flumequine and oxolinic acid greater than MIC for susceptible strains $\left(<0.0625 \mu \mathrm{g} \mathrm{m}^{-1}\right)$ were maintained for up to 6.5 and $8 \mathrm{~d}$ respectively for flumequine and oxolinic acid in muscle and 7.5 and $9 \mathrm{~d}$ respectively in abdominal organ homogenate
\end{abstract}

KEY WORDS: Halibut - Bath treatment - Quinolones - Antibacterial activity

\section{INTRODUCTION}

Flumequine (FLU) and oxolinic acid (OXA) are broad-spectrum synthetic antibacterial agents and members of the 4-quinolone series of antibacterials. Quinolones are especially active against Gramnegative bacteria and have been recommended for the treatment of urinary tract and enteric infections in humans (Wolfson \& Hooper 1989). The antibacterial activity of quinolones is based on the inhibition of

\footnotetext{
- Present address: Department of Clinical Biology, Section of Pharmacology, Armauer Hansens Hus, N-5021 Bergen, Norway. E-mail: ole.samuelsen@ikb.vib.no
}

DNA-gyrase resulting in an unstable condensation of the DNA configuration of the bacterial DNA molecule during cell division (Wolfson \& Hooper 1989). Flumequine and OXA have been used intensively to treat systemic bacterial infections such as furunculosis caused by Aeromonas salmonicida, vibriosis caused by Vibrio anguillarum and enteric redmouth disease caused by Yersinia ruckeri in fish (Michel et al. 1980, Austin et al. 1983, Rodgers \& Austin 1983, Scallan \& Smith 1985, O'Grady et al. 1988). The widespread use of FLU and OXA for the treatment of bacterial infections in fish is mainly due to their relatively low minimum inhibitory concentrations (MIC) for most susceptible fish pathogens (Martinsen 1993) and effective systemic distribution when adminis- 
tered orally via medicated feed (Chevalier et al 1981)

Injection into the peritoneal cavity or muscle represents the most effective and accurate means of administering a therapeutic dose of an antibacterial agent to an individual fish. However, since individual injection is costly in time and labour and causes stress to the fish it is inappropriate as a routine method of chemotherapy. At present, injection is only used in the treatment of valuable broodstock fish. Oral administration of drugs using food pellets containing the desired antibacterial substance permits treatment of large quantities of fish relatively easily at a moderate cost in labour and has become the prime route of medication. However, diseased fish often show reduced appetite, which together with hierarchical behaviour will result in uneven distribution of the antibacterial in the stock. This gives rise to a situation where only healthy individuals that are still feeding are protected by the antibacterial. Bath treatment offers an equal dose to both healthy and diseased fish and is easy to carry out with agents of sufficient water-solubility. Being restricted to tanks of limited size, bath treatment may be an alternative in treating small fish where the feed uptake is minimal due to infection, low temperature or early stages of development. It has previously been demonstrated that bath administration of erythromycin with surfactant could eliminate Aeromonas salmonicida from the intestine of fish (Roberts 1980). Bath treatment with FLU was shown to successfully eliminate stress inducible furunculosis in Atlantic salmon Salmo salar smolts (O'Grady \& Smith 1992). Bath administration of sulphonamides and trimethoprim has shown the drugs to be well absorbed in both rainbow trout Oncorhynchus mykiss and cod Gadus morhua (Bergsjø 1974, Bergsjø \& Bergsjø 1978, Bergsjø \& Søgnen 1980, Borgan et al. 1981).

Several studies have addressed the pharmacokinetics of OXA and FLU in fish held in seawater (Hustvedt \& Salte 1991, Hustvedt et al. 1991, Ishida 1992, Rogstad et al. 1993, Elema et al. 1994, Martinsen \& Horsberg 1995). However, information on the pharmacokinetic properties of quinolones administered by bath to halibut is not presently available in the literature

The aim of this study was to determine the absorption, tissue distribution and elimination of FLU and OXA in halibut following bath treatment, and also the in vitro MIC values for the drugs against some strains of Vibrio sp.

\section{MATERIALS AND METHODS}

Chemicals. Flumequine (FLU) and oxolinic acid (OXA) were obtained from Norsk Medisinaldepot
(Bergen, Norway). Methanol, acetonitrile, tetrahydrofuran (HPLC-grade), sodium hydroxide $(\mathrm{NaOH})$ and oxalic acid dihydrate were all from Mercks (Darmstadt, Germany\}.

Chromatography. The HPLC system used consisted of a Spectra-Physics SP 8800 ternary H.PLC-pump (Spectra-Physics, San Jose, CA, USA) connected to a Spectra-Physics SP 8780 X R Autosampler and a Shimadzu RF-535 fluorescence detector (Shimadzu, Kyoto, Japan) operating at an excitation wavelength of $325 \mathrm{~nm}$ and an emission wavelength of $360 \mathrm{~nm}$. The integrator was the model SP-4270 from SpectraPhysics. The HPLC system was programmed to inject $20 \mu \mathrm{l}$ samples into the $150 \times 4.6 \mathrm{~mm}$ analytical column packed with $3 \mu \mathrm{m}$ particles of MOS-Hypersil (C-8), (Shandon Southern Products, Astmoor, UK) in our laboratory using a Shandon column packing machine. The column was operated at room temperature. The mobile phase used contained $\mathrm{A}: 0.025 \mathrm{M}$ oxalic acid pH 3.2 - acetonitrile - methanol - tetrahydrofuran (80 $2.5-15-2.5 \mathrm{v} / \mathrm{v}$ ) and B: oxalic acid $\mathrm{pH} 3.2-$ acetonitrile - methanol - tetrahydrofuran $(50-20-25-5 \mathrm{v} / \mathrm{v})$. The solutions were filtered through a $0.2 \mu \mathrm{m}$ Millipore filter. The elusion profile was as follows: 0 to $4 \mathrm{~min} ., 50$ to $100 \% \mathrm{~B}$ linear gradient; 4 to $10 \mathrm{~min}$. isocratic $100 \% \mathrm{~B}_{i}$ 10.1 to $15 \mathrm{~min}$. isocratic $50 \% \mathrm{~A}$ and $50 \% \mathrm{~B}$. The flow rate was $1 \mathrm{ml} \mathrm{min.} .^{-1}$

Stock solutions of FLU and OXA were prepared at a concentration of $0.1 \mathrm{mg} \mathrm{ml}^{-1}$ in $0.1 \mathrm{M} \mathrm{NaOH}$ and stored at $-20^{\circ} \mathrm{C}$. Working standards were prepared by dilution from the stock solutions with $0.1 \mathrm{M} \mathrm{NaOH}$.

Experimental fish. Approximately 250 halibut obtained from Tinfos Aqua (Kvinesdal, Norway), ranging in weight from 3 to $5 \mathrm{~g}$, were maintained in a circular ( $1 \mathrm{~m} \times 2.5 \mathrm{~m}$ i.d.) flow-through seawater tank at the laboratory of the Institute of Marine Research, Bergen, Norway. The seawater had a salinity of $33 \%$ and a temperature of $12.0 \pm 0.5^{\circ} \mathrm{C}$. Ten fish were taken prior to initiation of the study and analysed by HPLC to confirm the absence of FLU and OXA from the tissues. Tissues from these fish also served as samples for the calibration curves.

Bath administrations. The bath administrations were carried out in $40 \mathrm{l}$ glass aquaria containing $20 \mathrm{l}$ of the drug solution. The drugs were dissolved in $50 \mathrm{ml}$ of a $0.025 \mathrm{M}$ solution of $\mathrm{NaOH}$ and added to the seawater to a final concentration of $150 \mathrm{mg} \mathrm{l}^{-1}$ of FLU or $200 \mathrm{mg}$ $\mathrm{I}^{-1}$ of OXA. It was decided to use a FLU concentration of $150 \mathrm{mg} \mathrm{l}^{-1}$ in the bath due to lethality on 1 of 5 fish in a preliminary experiment using a bath concentration of $200 \mathrm{mg} \mathrm{l}^{-1}$. Extremely high concentrations of FLU in both muscle (136.4 $\mathrm{gg} \mathrm{g}^{-1}$ ) and abdominal organ homogenate $\left(580.8 \mathrm{\mu g} \mathrm{g}^{-1}\right)$ was found in the dead fish. Administration of FLU by bath or by injection has shown to be capable of causing lethal concentrations of 
the drug in Atlantic salmon smolts (Scallan 1983, O'Grady \& Smith 1992). A possible link between oral administration of FLU to Atlantic salmon pre-smolts and lethality has been described by Hiney et al. (1994). The bath solutions were aerated and the aquaria equipped with a filter-pump to remove fecal particles. Twenty-four hours prior to initiating bath treatment the test fish were transferred to the aquaria for acclimatisation. The fish were kept in the drug solution for $72 \mathrm{~h}$ followed by transfer of the remaining fish to flowthrough seawater tanks containing unmedicated seawater. Six fish were removed at 24,48 and $72 \mathrm{~h}$ during treatment and at the following times post treatment: 1 , $3,5,7,10$ and $14 \mathrm{~d}$. The sampled fish were rinsed in clean seawater in order to avoid contamination of the samples by drug-containing water. The fish were killed by a blow to the head and kept at $-20^{\circ} \mathrm{C}$ until analysed.

Sample preparation. Samples of muscle and abdominal organ homogenate $(0.1 \mathrm{~g})$ were homogenised in $1.0 \mathrm{ml}$ of $0.1 \mathrm{M} \mathrm{NaOH}$ solution containing the internal standard. Following homogenisation, $0.5 \mathrm{ml}$ of the homogenate was transferred to a polypropylene tube. After centrifugation at $12900 \times g$ in a Biofuge 13 tablecentrifuge (Heraeus Sepatech, Osterode am Harz, Germany) for 5 min. and filtration of the supernatant through an Acrodisc LC PVDF $0.45 \mu \mathrm{m}$ syringe filter (Gelman Sciences, Ann Arbor, MI, USA) a clear supernatant was obtained, ready for analysis. The method had a detection limit of $0.05 \mu \mathrm{g} \mathrm{g}^{-1}$ Flumequine was used as internal standard for the determination of OXA and vice versa. Due to the small size of the fish it was difficult to obtain individual samples of the organs. It was therefore decided to use a homogenate of the abdominal organs as one sample. The abdominal organ homogenate consisted mainly of liver, stomach and intestine.

Data handling. In the depletion phase, linear regression analysis were performed on logarithmically (In) transformed tissue concentrations versus time. Elimination half lives $\left(t_{1 / 2}\right)$ were calculated from the monoexponential slope for the drug elimination. Values below the limit of detection were assumed to be zero and eliminated from the calculations. The corresponding elimination times $\left(E_{t}\right)$ were calculated as the time were the regression line intercepts with a residue concentration of $0.05 \mathrm{\mu g} \mathrm{g}^{-1}$ for the respective drugs. At present no official maximum residue limit (MRL) has been decided by the European Union for OXA or FLU in food products.

Minimum inhibitory concentration (MIC) determinations. Determination of MIC values was performed using the agar dilution method (Washington 1985). Strains were maintained on Mueller Hinton Agar (Difco) supplemented with $2 \% \mathrm{NaCl}$. Material from strains to be examined was transferred to $10 \mathrm{ml}$ Difco Mueller Hinton Broth (Difco) supplemented with $2 \%$ $\mathrm{NaCl}$ and incubated for $48 \mathrm{~h}$ at $20^{\circ} \mathrm{C}$ giving a final cell density of approximately $5 \times 10^{8}$ cells $\mathrm{ml}^{-1}$. Using a $10 \mu$ inoculation loop, bacteria from this broth were distributed on the surface of Mueller Hinton Agar supplemented with $2 \% \mathrm{NaCl}$ and containing FLU or OXA. The antibacterial agents were added to the agar in 2 -fold dilutions from newly prepared stock solutions. The temperature of the agar on addition of the agents were $50^{\circ} \mathrm{C}$. Following incubation at $20^{\circ} \mathrm{C}$ for $72 \mathrm{~h}$ the plates were examined for bacterial growth. The lowest concentration of FLU and OXA at which complete inhibition occurred was recorded as the MIC.

Bacterial strains. In the determination of MIC values the following bacterial strains were examined: Vibrio anguillarum serotype $O 1$ (HI 11341), $V$. anguillarum serotype $\mathrm{O} 2 \alpha$ (HI 11347), V. salmonicida (HI 10448) and $V$. splendidus (1576/92). The first 2 strains are pathogenic to halibut whereas the strains of $V$. salmonicida and $V$. splendidus are non-pathogenic but were originally isolated from halibut $(\varnothing$. Bergh, Institute of Marine Research, Bergen, pers. comm.).

\section{RESULTS}

No lethality was observed during or after treatment. The mean concentration versus time profiles for FLU and OXA in muscle and abdominal organ homogenate are given in Figs. 1 \& 2. Fish-to-fish variation expressed as standard deviation are given as error bars. The $\%$ standard deviation ranged from 4 to $24 \%$ and 10 to $21 \%$ respectively for FLU and OXA in muscle and from 14 to $26 \%$ and 10 to $46 \%$ respectively for

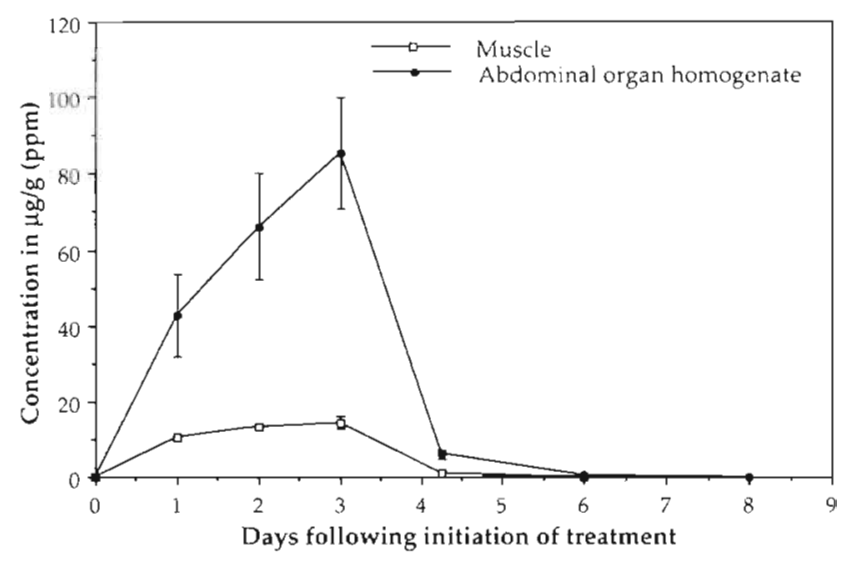

Fig. 1. Hippoglossus hippoglossus. Concentration versus time curves for flumequine in muscle and abdominal organ homogenate of halibut during and following bath treatment in $150 \mathrm{mg} \mathrm{l}^{-1}$ of the drug for $72 \mathrm{~h}$ 


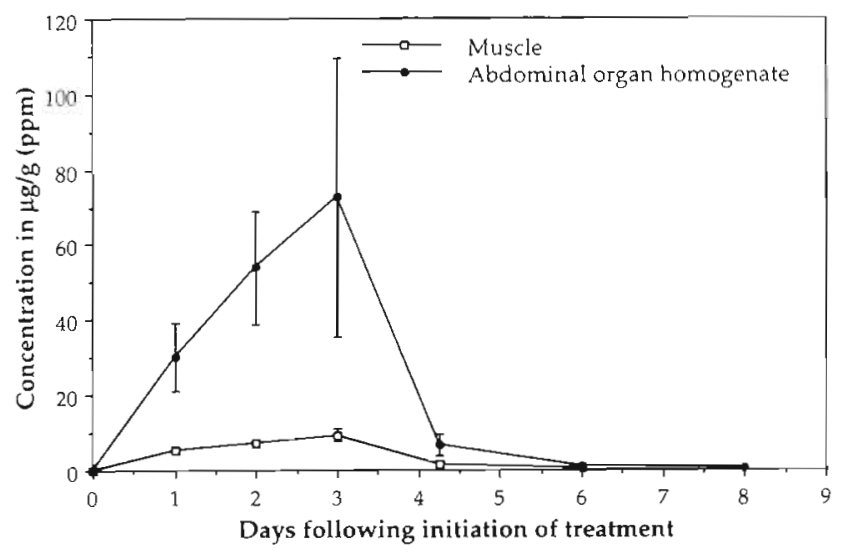

Fig. 2. Hippoglossus hippoglossus. Concentration versus time curves for oxolinic acic in muscle and abdominal organ homogenate of halibut during and following bath treatment in $150 \mathrm{mg} \mathrm{^{-1 }}$ of the drug for $72 \mathrm{~h}$

abdominal organ homogenate. Peak concentrations for FLU and OXA following a $72 \mathrm{~h}$ bath treatment were 14.2 and $9.4 \mu \mathrm{g} \mathrm{g}^{-1}$ respectively in muscle and 85.4 and $72.6 \mu \mathrm{g} \mathrm{g}^{-1}$ respectively in abdominal organ homogenate. At Day 7 post treatment, the drug concentrations in all samples were below the detection limit of the analytical method used. The elimination half lives $\left(t_{1 / 2}\right)$ were calculated to be 10 and $15.6 \mathrm{~h}$ respectively for FLU and OXA in muscle and 9.8 and 15.0 h respectively in abdominal organ homogenate. The corresponding elimination times $\left(E_{t}\right)$ were determined to be 6.5 and $8 \mathrm{~d}$ respectively in muscle and 7.5 and $9 \mathrm{~d}$ respectively in abdominal organ homogenate using a maximum residue concentration of $0.05 \mathrm{\mu g} \mathrm{g}^{-1}$. The correlation value $\left(\mathrm{I}^{2}\right)$ for the slops from which $t_{1 / 2}$ and $E_{t}$ were calculated were $0.99,0.99$ and 0.98 respectively for muscle and abdominal organ homogenate (FLU) and muscle (OXA). The correlation value for OXA in abdominal organ homogenate was 0.944. No indications of 2-phase elimination for either of the drugs was found. The MICs against the bacterial strains tested in this investigation ranged from 0.015 to $1.0 \mu \mathrm{g} \mathrm{ml}^{-1}$ for FLU and from 0.015 to $0.5 \mathrm{\mu g} \mathrm{ml}^{-1}$ for OXA (Table 1).

\section{DISCUSSION}

The analysis showed high concentrations of both FLU and OXA in muscle and abdominal organ homogenate of halibut. Following a $72 \mathrm{~h}$ bath treatment with $150 \mathrm{mg} \mathrm{l}^{-1} \mathrm{FLU}$ and $200 \mathrm{mg} \mathrm{l}^{-1}$ OXA, peak concentrations of $14.2 \mu \mathrm{g} \mathrm{g}^{-1}$ (FLU) and $9.4 \mu \mathrm{g} \mathrm{g}^{-1}$ (OXA) in muscle and $85.4 \mu \mathrm{g} \mathrm{g}^{-1}$ (FLU) and $72.6 \mu \mathrm{g} \mathrm{g}^{-1}$ (OXA) in abdominal organ homogenate were obtained. These concentrations are similar or consider-
Table 1. In vitro activity of flumequine and oxolinic acid against Vibrio sp.

\begin{tabular}{|llll|}
\hline Strain & & \multicolumn{2}{c|}{$\begin{array}{c}\text { MIC }\left(\mu \mathrm{ml}^{-1}\right) \\
\text { Flumequine Oxolinic } \\
\text { acid }\end{array}$} \\
\hline Vibrio anguillarum O 1 & HI 11341 & 0.06 & 0.03 \\
Vibrio anguillarum O 2 $\alpha$ HI 11347 & 0.015 & 0.015 \\
Vibrio salmonicida & HI 10448 & 0.03 & 0.03 \\
Vibrio splendidus & $1576 / 92$ & 1.00 & 0.5 \\
\hline
\end{tabular}

ably higher than the concentrations achieved following oral administration of these drugs to fish held in seawater. Peak concentrations following oral administration of FLU to Atlantic salmon $\left(25 \mathrm{mg} \mathrm{kg}^{-1} \mathrm{~d}^{-1}\right.$ for $6 \mathrm{~d})$ were 9 and $14 \mu \mathrm{g} \mathrm{g}^{-1}$ respectively in muscle and liver (Elema et al. 1994). In a study by Rogstad et al. (1993) peak concentrations were 6.58 and $19.5 \mu \mathrm{g} \mathrm{g}^{-1}$ respectively for FLU in muscle and liver of Atlantic salmon treated with a single oral dose of $25 \mathrm{mg} \mathrm{kg}^{-1}$ fish $^{-1}$. The corresponding values for OXA were 5.72 and $6.83 \mu \mathrm{g} \mathrm{g}^{-1}$. Ishida (1992) found peak tissue concentrations of $1.2 \mu \mathrm{g} \mathrm{g}^{-1}$ in muscle and $1.8 \mu \mathrm{g} \mathrm{g}^{-1}$ in liver following a single oral administration of $40 \mathrm{mg}$ $\mathrm{kg}^{-1}$ of OXA to rainbow trout.

Figs. 1 \& 2 show that both FLU and OXA were rapidly eliminated from muscle and abdominal organ homogenate of halibut. The $t_{1 / 2}$ of OXA in halibut were calculated to 15.0 and $15.6 \mathrm{~h}$ respectively in muscle and abdominal organ homogenate. This is shorter than the $17.6 \mathrm{~h}$ in muscle and $21.2 \mathrm{~h}$ in liver of Atlantic salmon found by Elema et al. (1994) but longer than the $10 \mathrm{~h}$ in plasma, muscle and liver of Atlantic salmon reported by Rogstad et al. (1993). The $t_{1 / 2}$ of FLU in halibut were estimated to $10.0 \mathrm{~h}$ in muscle and $9.8 \mathrm{~h}$ in abdominal organ homogenate, which is shorter than any previous reported values. In earlier studies, $t_{1 / 2}$ of FLU was found to be 23 and $17.6 \mathrm{~h}$ in muscle and 23 and $21.2 \mathrm{~h}$ in liver of Atlantic salmon (Rogstad et al. 1993, Elema et al. 1994). Calculated plasma $t_{1 / 2}$ for FLU and OXA in Atlantic salmon and rainbow trout held in seawater varies from 11.3 to 22.8 h for FLU (Martinsen 1993, Rogstad et al. 1993, Elema et al. 1994, Martinsen \& Horsberg 1995) and 10 to $60.3 \mathrm{~h}$ for OXA (Hustvedt \& Salte 1991, Hustvedt et al. 1991, Rogstad et al. 1993, Martinsen \& Horsberg 1995). The times for FLU and OXA to reach a tissue concentration of $0.05 \mu \mathrm{g} \mathrm{g}^{-1}$ were 6.5 and $8 \mathrm{~d}$ respectively for muscle and 7.5 and $9 \mathrm{~d}$ respectively for abdominal organ homogenate. Although these calculations are derived from data obtained from small fish and cannot be direct extrapolated to larger fish, they indicate short withdrawal times for both quinolones in tissues of halibut. 
The in vitro MIC-values for FLU and OXA against the bacterial strains tested ranged from 0.015 to $1.0 \mu \mathrm{g}$

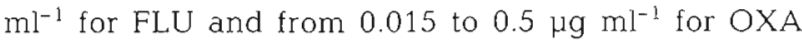
(Table 1). Previous studies report MIC's of FLU and OXA against strains of Aeromonas salmonicida, Vibrio salmonicida, $V$. anguillarum and Yersinia ruckeri to range from 0.005 to $0.5 \mu \mathrm{g} \mathrm{ml}^{-1}$, and most of the strains had MICs of $<0.1 \mu \mathrm{g} \mathrm{ml}^{-1}$ (Barnes et al. 1990, Martinsen et al. 1992. Martinsen 1993). According to the guidelines proposed by Tsoumas et al. (1989), a bacterium is susceptible to FLU and OXA if the in vitro $\mathrm{MIC}$ is $<0.0625 \mu \mathrm{g} \mathrm{ml} \mathrm{m}^{-1}$ and moderately susceptible when the MIC is within the range of 0.125 to $0.5 \mu \mathrm{g}$ $\mathrm{ml}^{-1}$. With a MIC of $\geq 1.0 \mu \mathrm{g} \mathrm{ml}^{-1}$ a strain is classified as resistant. Using this guideline, 3 of 4 strains examined were susceptible to OXA and one was moderately susceptible whereas 2 strains were susceptible to FLU, one was moderately susceptible and one was resistant. Standard oral therapy with FLU to fish in Norway is $25 \mathrm{mg} \mathrm{kg}^{-1} \mathrm{~d}^{-1}$ for 5 to $8 \mathrm{~d}$ and $40 \mathrm{mg} \mathrm{kg}^{-1} \mathrm{~d}^{-1}$ for 5 to $8 \mathrm{~d}$ for OXA. The results from this investigation show that bath treatment using FLU and OXA at concentrations of 150 and $200 \mathrm{mg} \mathrm{l}^{-1}$ respectively for $72 \mathrm{~h}$ maintained muscle levels in excess of an MIC-value of $0.0625 \mu \mathrm{g} \mathrm{ml}^{-1}$ for at least $6.5 \mathrm{~d}$ for FLU and $8 \mathrm{~d}$ for OXA. The corresponding values were 7.5 and $9 \mathrm{~d}$ respectively for FLU and OXA in abdominal organ homogenate.

When a drug is added to water, there are several possible absorption routes. Absorption of drugs through the gills is assumed to be of major importance whereas absorption through the skin is of relatively little significance (Parry 1966). In seawater drugs can be absorbed via the intestine as a result of the fish drinking the surrounding medium (Motais \& Garcia-Romeu 1972). Bergsjø \& Bergsjø (1978) showed that the uptake of sulphadimidine and sulphanilamide in rainbow trout was higher from salt water at $\mathrm{pH} 8.0$ than from fresh water at $\mathrm{pH}$ 8.0. This indicates a supplementary absorption from the gut. However, the absorption rate of FLU and OXA measured in this investigation is very slow compared to the absorption rate of FLU in fish held in freshwater (O Grady et al. 1988, Hiney et al. 1995). This indicate the presence of factors inhibiting absorption in seawater. An $18 \mathrm{~min}$ treatment in a freshwater bath with a FLU concentration of $25 \mathrm{mg} \mathrm{l}^{-1}$ and a pH of 6.5 gave peak muscle concentrations of 14 and $18.5 \mu^{-1} g^{-1}$ in 2 groups of Atlantic salmon smolt (Hiney et al. 1995). O'Grady et al. (1988) obtained serum levels of approximately $5 \mu \mathrm{g} \mathrm{ml}^{-1}$ of FLU in Atlantic salmon smolts following bath treatment in a $100 \mathrm{mg} \mathrm{l}^{-1}$ freshwater solution of $\mathrm{pH} 8.0$ for $30 \mathrm{~min}$. In the same investigation it was shown that the absorption rate of FLU in brown trout Salmo trutta and Atlantic salmon smolts was highly dependent on $\mathrm{pH}$ and the presence of calcium ions $\left(\mathrm{Ca}^{2+}\right)$ in the solution. A progressive decline in uptake occurred when $\mathrm{pH}$ was increased from 6.5 to 8 and the $\mathrm{Ca}^{2+}$ level in the solution was raised from 0 to $75 \mathrm{mg} \mathrm{l}^{-1}$ At higher $\mathrm{Ca}^{2+}$ levels the decrease in FLU absorption was less pronounced. Recent research has also shown that the concentration of magnesium $\left(\mathrm{Mg}^{2+}\right)$ ions found in seawater have marked effect on both the antibacterial activity and uptake of various antibacterials by fish (Lunestad \& Goksøyr 1990, Barnes et al. 1995, Pursell et al. 1995). Seawater contains approximately 10 and $54 \mathrm{mM}$ respectively of $\mathrm{Ca}^{2+}$ and $\mathrm{Mg}^{2+}$ ions and has a $\mathrm{pH}$ of approximately 8.0. The unfavourable conditions for FLU and OXA absorption in seawater compared to freshwater may explain the large differences in the absorption rates obtained in this study and the studies by O'Grady et al. (1988) and Hiney et al. (1995).

Excluding the measurements of OXA in abdominal organ homogenate after $72 \mathrm{~h}$, Figs. 1 \& 2 show that the fish to fish variation in drug concentration is small. From plasma data obtained in a multiple dose study with oral administration of FLU to healthy Atlantic salmon much higher \% standard deviations of 25 to $65 \%$ could be calculated (Elema et al. 1994). These results indicate that the fish to fish variation is smaller using bath treatment compared to oral administration. In commercial conditions the feeding response will be via an infected population where it is reasonable to predict that the extent of fish-to-fish variation will be even greater than that calculated from data obtained by Elema et al. (1994). In addition to the low fish-to-fish variation in tissue concentrations a second advantage of bath treatment is that fish do not need to be actively feeding in order to receive therapeutic tissue levels.

\section{CONCLUSION}

In summary this study shows that bath treatment using FLU and OXA is an alternative to oral administration as a chemotherapeutic method in the control of bacterial infections in small halibut. Both FLU and OXA were absorbed in sufficient amounts to achieve and maintain tissue levels greater than the in vitro $\mathrm{MIC}$ values for susceptible pathogens for at least $6.5 \mathrm{~d}$. Provided that oxygenation is adequate, it is possible to treat a large number of fish in a comparatively small volume of water. The procedure is simple and allows the user to dispose of and destroy the remains of the drugs in a controlled manner. Due to environmental aspects and the large amount of drug needed for the treatment, this technique is however not suitable for sea cage application. Further research is needed to evaluate the maximim size of halibut suitable for bath treatment. 
Acknowledgements. This work was funded by the Norwegian Research Council. The technical assistance of Mrs Laila Unneland, Mr Audun Hoylandkjæer and Mr Hari Rudra is highly appreciated. Thanks also to Mr Odd Magne Rodseth at Intervet Norbio and Mr Yngve Torgersen at the Royal Norwegian Ministry of Agriculture, Department of Veterinary Services for providing the bacterial strains.

\section{LITERATURE CITED}

Austin B, Rayment J, Alderman DJ (1983) Control of furunculosis by oxolinic acid. Aquaculture 31:101-108

Barnes AC, Lewin CS, Hastings TS, Amyes SGB (1990) In vitro activities of 4 -quinolones against the fish pathogen Aeromonas salmonicida. Antimicrob Agents Chemother $34: 1819-1820$

Barnes AC, Hastings TS, Amyes SGB (1995) Aquaculture antibacterials are antagonized by seawater cations. J Fish Dis 18:463-465

Bergsjø $T$ (1974) The absorption of sulfadimidine from cod (Gadus morhua). Acta Vet Scand 15:442-444

Bergsjø T, Bergsjø TH (1978) Absorption from water as an alternative method for administration of sulphonamides to rainbow trout (Salmo gairdneri R.). Acta Vet Scand 19 $102-109$

Bergsjø T, Søgnen E (1980) Plasma and tissue levels of trimethoprim in the rainbow trout, Salmo gairdneri, after absorption from fresh and salt water. Acta Vet Acand 21: $18-25$

Borgan A, Ødegaard S, Bergsjø T (1981) Temperature related absorption and excreetion of sulfadimidine in rainbow trout (Salmo gairdneri R.). Acta Vet Scand 22:211-217

Chevalier R, Gerard JP, Michel C (1981) Distribution et cinétique tissulaire de la flumequine chez la truite arc-en-ciel (Salmo gairdneri, Richardson). Rev Méd Vét 132:831-837

Elema MO, Hoff KA, Kristensen HG (1994) Multiple-dose pharmacokinetic study of flumequine in Atlantic salmon (Salmo salar L.). Aquaculture 128:1-11

Hiney MP, Coyne R, Kerry J, Pursell L, Samuelser. OB, Smith $P$ (1995) Failure of Flumisol bath treatments during commercial transport of salmon smolts to prevent the activation of stress inducible furunculosis. Aquaculture 136: $31-42$

Hiney MP, Samuelsen OB, Smith P (1994) Association of mortalities in a salmon hatchery with the oral administration of flumequine. Bull Eur Ass Fish Pathol 14:204-206

Hustvedt SO, Salte R (1991) Distribution and elimination of oxolinic acid in rainbow trout after a single rapid intravascular injection. Aquaculture 92:297-303

Hustvedt SO, Salte R, Vassvik V (1991) Absorption, distribution and elimination of oxolinic acid in Atlantic salmon (Salmo salar) after various routes of administration. Aquaculture 92:193-199

Ishida $N$ (1992) Tissue levels of oxolinic acid after oral or intravascular administration to freshwater and seawater rainbow trout. Aquaculture 102:9-15

Lunestad BT, Goksøyr J (1990) Reduction un the antibacterial effect of oxyletracycline in seawater by complex formation

Responsible Subject Editor: D. W. Bruno, Aberdeen, United Kingdom with magnesium and calcium. Dis Aquat Org 9:67-72

Martinsen B (1993) Quinolones as antimicrobial drugs in aquaculture: antimicrobial activities and pharmacokinetic properties. Dr scient thesis, Norwegian College of Veterinary Medicine, As

Martinsen B, Horsberg TE (1995) Comparative single-dose pharmacokinetics of four quinolones, oxolinuc acid, flumequine, sarafloxacin and enrofloxacin in Atlantic salmon (Salmo salar) held in seawater at $10^{\circ} \mathrm{C}$. Antimicrob Agents Chemother 39:1059-1064

Martinsen B, Oppegaaard H, Wichstrom R, Myhr E (1992) Temperature-dependent in vitro antimicrobial activity of four 4-quinolones and oxytetracycline against bacteria pathogenic to fish. Antimicrob Agents Chemother 36: $1738-1743$

Michel C, Gerard JP, Fourbet B, Collas R, Chevalier R (1980) Emploi de la flumequine contre la furunculose des salmonides: essais therapeutiques et perspectives pratiques. Bull Franc Piscicult 277:154-162

Motais R, Garcia-Romeu F (1972) Transport mechanisms in the teleostean gill and amphibian skin. Ann Rev Physiol 34:141-176

O'Grady P, Moloney M, Smith PR (1988) Bath administration of the quinolone antibiotic flumequine to brown trout (Salmo trutta) and Atlantic salmon (Salmon salar). Dis Aquat Org 4:27-33

O'Grady P, Smith P (1992) Use of Flumisol bath treatment to eliminate stress inducible furunculosis in salmon smolts. Bull Eur Ass Fish Pathol 12:201-203

Parry G (1966) Osmotic adaption in fishes. Biol Rev 41:392-441

Pursell L, Samuelsen OB, Smith P (1995) Reduction in the invitro activity of flumequine against Aeromonas salmonicida in the precence of the concentrations of divalent cations found in sea water. Aquaculture 135:245-255

Roberts SD (1980) A method of reducing the carrier state of Aeromonas salmonicida in juvenile pacific salmon. PhD thesis, University of Idaho, Moscow

Rodgers CJ, Austin B (1983) Oxolinic acid for control of enteric redmouth disease in rambow trout. Vet Rec 112:83

Rogstad A, Ellingsen OF, Syvertsen C (1993) Pharmacokınetics and bioavailability of flumequine and oxolinic acid after various routes of administration to Atlantic salmon in seawater. Aquaculture 110:207-220

Scallan A (1983) Investigations into asymptomatic carriers of furunculosis. PhD thesis, National University of Ireland. Dublin

Scallan A, Smith PR (1985) Control of asymptomatic carriage of Aeromonas salmonicida in Atlantic salmon smolts with flumequine. In: Ellis AE (ed) Fish and shellfısh pathology. Academic Press, London, p 119-127

Tsoumas A, Alderman DJ, Rogers CJ (1989) Aeromonas salmonicida: development of resistance to 4-quinolone antibacterials. J Fish Dis 12:493-507

Washington II JA (1985) Susceptibility tests: agar dilution. In: Lennette EH, Balows A. Hausler WJ Jr, Shadomy HJ (eds) Manual of clinical microbiology, 4th edn. American Society for Microbiology, Washington, DC, p 967-971

Wolfson JS, Hooper DC (1989) Fluoroquinolone antimicrobial agents. Clin Microbiol Rev 2(4):378-424

Manuscript hrst recelved: January 3, 1996

Revised version accepted: June 4, 1996 